\title{
Multimedia Web-Based Constructivist Learning Application for Information Literacy Skills Development
}

\author{
Mohd Nasir Ismail ${ }^{1}$, Nurfaezah Mamat ${ }^{2}$ \\ ${ }^{I}$ Faculty of Information Management, UiTM; nasir733@kelantan.uitm.edu.my \\ ${ }^{1}$ Faculty of Information Management, UiTM; nurzah@gmail.com \\ https://doi.org/10.37134/jictie.vol6.2.2019
}

\begin{abstract}
The purpose of this study is to design and develop a multimedia web-based constructivist learning application known as WebOPAC Self Training Tool with Guided Exploration (WSTTG) which is expected to train and access individual's information literacy skills. This tool has been designed and developed according to the constructivist instructional design theories and constructivist instructional development model. The process design consists of four level processes which were component design, single path prototype, alpha version and beta version. The development process ended with four activities which were summative evaluation, final packaging, diffusion and adoption. Throughout the design and development process, there were two instructional designers and two subject matter experts were participated to review and evaluate the design components of the WSTTG. Three potential learners were also participated to evaluate the beta version prototype whether it is appropriately apply to their learning context. The repetition of reviewing the alpha and beta version prototypes lasted when there were no comments found during the final evaluation. Overall, all experts and learners were satisfied with the interface, surface characteristics, scenario, and instructional strategies used in the prototype after consideration on comments and suggestions have been made accordingly. This tool was recommended to be commercialized as an instructional strategy for library orientation program and to be used by both the librarians and library users for WebOPAC teaching and learning purposes. The design and development of this tool could be a guideline to future instructional designers, web developers and e-learning content specialist in developing a multimedia web-based constructivist application in various fields.
\end{abstract}

Keywords: information literacy skills, multimedia development process, web-based application, constructivist learning.

\section{INTRODUCTION}

Libraries have been forced to undergo drastic changes during the last few years. While the traditional library was mainly a space for physical books and journals, the library of today has developed into a "digital library" with access to enormous numbers of information sources through Internet. The role of a library is to support student's information needs by providing relevant resources and service effectively. The mission of any library is to disseminate information and to make effective use of its resource. To use the library efficiently, the user should know about the availability of different sources within the library and thus can reach for the sources of its interest in the library. 
Generally, academic libraries of Malaysian universities were actively conducting their various library orientation programs, library skill trainings, library research trainings, information skills trainings and other similar trainings whose main aim is to educate the user on information use, bibliographic education and information literacy skills (Lanning \& Mallek, 2017; Kim \& Shumaker, 2015; Kumar, 2014; Anunobi \& Udem, 2014, Simon, 2013; Klaib, 2011; Ramli, Fun, \& Idris, 2009). Library orientation trainings are compulsory for every new student and are conducted usually at the beginning of every academic year or semester. Throughout the year, the libraries will organize program with the aim of familiarizing the students with the various tools within the libraries. This program is a way to help new students familiarize themselves with the layout, regulations, types of services and facilities offered by the particular academic library.

Information Literacy (IL) is one of the critical digital-age illiteracies for higher education. Thanuskodi (2013) and Kim and Shumaker (2015) defined that IL is a way to move efficient access, evaluation and use of information which should be taken into account and used for improving end users information. Association of College and Research Libraries (ACRL, 2011) defined that IL is a set of abilities requiring individuals to recognize information need and have ability to locate, evaluate, and use needed the information effectively. Therefore, the library orientation programs need continuously improvement to be considered seriously by academic library to develop information literacy skill among undergraduates which will allow them to function in an information society as envisioned in Malaysian Vision 2020 (Jyoon \& Ibrahim, 2015; Edzan, 2008). Thus, students need to be information literate to cope with the challenges for future studies and profession.

\section{PROBLEM STATEMENT}

The Association of College and Research Libraries (ACRL) provided a standard which is Information Literacy Competency Standards for Higher Education as a guideline that will assist student in learning how to use the information, describe, locate, satisfies, evaluate and use the information need effectively (ACRL, 2011, 2014). Recent studies found that few problems facing during practicing information literacy training which relate to the ineffective way and strategy of conducting library tours, introductory information skills classes, and in teaching advanced information skills. As the result, the information literacy training during the orientation sessions does not comply with ACRL's standards (Shao \& Purpur, 2016; Derakhshan, Hassanzadeh, \& Nazari, 2015; Nurfaezah Mamat, Mohd Nasir Ismail \& Adnan Jamaludin, 2014; Magnuson, 2013; Baro \& Keboh, 2012; Husaini, Aziz, Karim, Jamin \& Saad, 2011; Syamalamba, 2011; Gullikson, 2006). They major finding and supported by Nurfaezah Mamat et al. (2014); Rice and Gregor (2013); Gregory and Broussard (2011) concluded that the ineffective way and strategy of conducting these orientations programs contribute to the deficiencies of information literacy skill among university students.

Mole, Chatzilia, Paraskevopoulos, Garoufallou, and Siantri (2013) claimed that web-based instruction brings an innovate perspective to library services, as it enhances the distribution of information, by 
eliminating time and place constrains, in addition to its considerable pedagogical potentials. It has become an ideal solution for information literacy development. Its active character allows and promotes interaction between the learner and the systems and in some cases with the IL instructor as well.

Thus, the aim of this study is to design and develop a unique and novel learning strategy known as WebOPAC Self Training Tool with Guided Exploration (WSTTG) which is expected to train and access individual's IL skills.

\section{DESIGN AND DEVELOPMENT PROCESS}

This section provides a description of the related theories and models that formed the instructional design theoretical foundation of WSTTG multimedia application. This section also provides a description of the related constructivist instructional development model that guided the design and development of the constructivist multimedia web-based learning environment.

The WSTTG instructional design has been developed according to the constructivist instructional design theories and constructivist instructional development model which follows the constructivist paradigm of instructional design which proposed by Reigeluth (1999). According to Reigeluth (1999), learning-focused instructional design theory must offer guidelines for the design of learning environment that provide appropriate combinations of challenge and guidance, empowerment and support, self-direction and structure which is a process in helping the learners to build their own knowledge.

The constructivist instructional design theories composed of two subcategories that are macro strategies and micro strategies. The macro strategies were based on the instructional goal theory (Gagne \& Merrill, 1990) and constructivist learning environments theory (Jonassen, 1999; Hannafin, Land, \& Oliver, 1999). The micro strategies were based on the cognitive theory of multimedia learning (Mayer, 2002) and theory of principles design of instructional multimedia (Mayer, 2002). While the constructivist instructional development model applies the reflective, recursive, design and development (R2D2) model (Willis, 1995) and later revised in Willis and Wright (2000) which consists of two development environment components which are the tools of design and the process of design. The constructivist's instructional design theoretical foundation and instructional development process model of WSTTG multimedia application are as in Figure 1. 


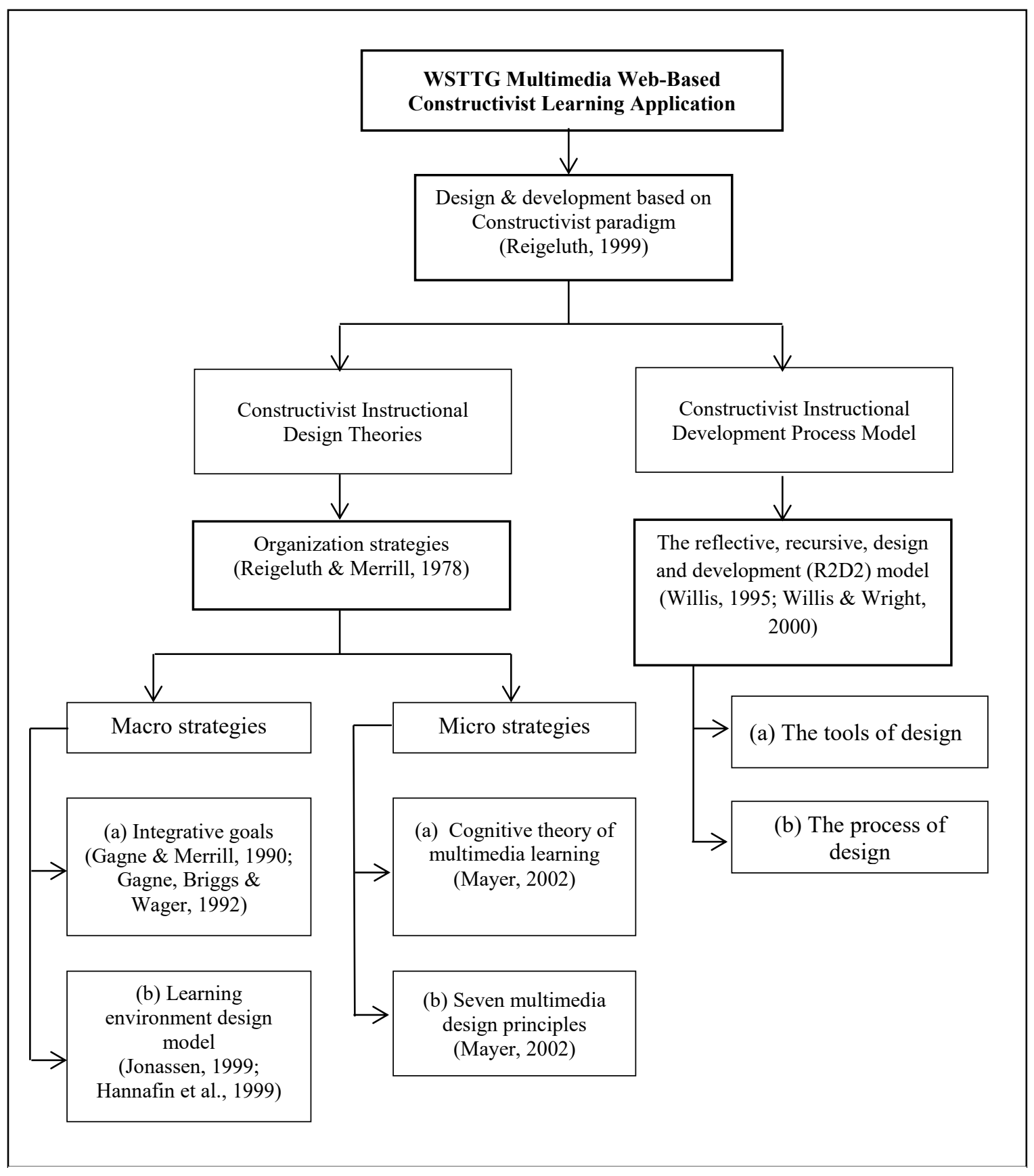

Figure 1: The constructivist's instructional design theoretical foundation and instructional development process model of WSTTG multimedia application. 


\section{CONSTRUCTIVIST INSTRUCTIONAL DESIGN THEORIES}

Generally, constructivists believe that learners can learn better when they are actively involved in a constructing knowledge in a learning-by-doing situation which in line with the Association of College and Research Libraries (ACRL) Information Literacy Standard and Bloom Taxonomy standard. Organisational strategies that proposed by Reigeluth and Merrill (1978) was being used in designing the learning activities. It composed of two subcategories that are macro strategies and micro strategies. The macro strategies concern with the selection, sequence, and organisation of the subject-matter topics that are to be presented (Gibbons, Fairweather, Anderson, \& Merrill, 1997). While micro strategies concern with the individual displays, including their characteristics, interrelationships and sequence that are to be presented to the learner which also known as presentation strategies. These strategies are consistent with the constructivist approach which was adopted in the macro strategies.

\section{Macro Strategies}

The first macro strategy in selecting, sequencing and organizing the subject-matter topics was based on the Gagne and Merrill (1990) which focus on the integrative instructional goal which is known as enterprise. The enterprise refers to a purposive activity that may depend for its execution on some combination of verbal information, intellectual skills and cognitive strategies (Gagne, Briggs \& Wager, 1992). By applying the integrative goals to the instructional design, the identification of the types of learning and the respective learning objectives (as listed in Table 1) represented the starting point of the design process.

In other words, an instructional designer needs to identify the component skills and knowledge that relate to the goal and designs the scenarios that related each piece of knowledge or skill to the goal. The integrative goal is incorporated within the enterprise schema as verbal knowledge. In this learning environment, the integrative goal was identified as the learners' abilities to interpret the basic rules of the used WebOPAC system that comprised the ordinary basic search, advance search, searching strategy and various searching tips.

Table 1: Type of Learning with the Corresponding Learning Objectives

\begin{tabular}{|c|c|}
\hline Types of learning & Learning objectives \\
\hline Label & $\begin{array}{l}\text { - } \quad \text { Name the various subject of WebOPAC (basic search, advance search). } \\
\text { - } \quad \text { Name the types of search strategies (searching strategies, searching tips). } \\
\text { - } \quad \text { Name of the searching process. }\end{array}$ \\
\hline $\begin{array}{l}\text { Verbal } \\
\text { Information }\end{array}$ & $\begin{array}{l}\text { - } \quad \text { Describe the meaning of various WebOPAC instructions. } \\
\text { - } \quad \text { Describe the meaning of common line markings. }\end{array}$ \\
\hline Intellectual skill & $\begin{array}{l}\text { - Identify the basic rules of each section (introduction, objective and the time } \\
\text { suggest of each section). } \\
\text { Distinguish the various types searching (basic search, guided search, searching } \\
\text { technique, searching tips and exercises). } \\
\text { - } \quad \text { Identify each step of the searching techniques. } \\
\text { - } \quad \text { Provide the exercises. }\end{array}$ \\
\hline
\end{tabular}


continue...

\begin{tabular}{cll}
\hline Types of learning & \multicolumn{2}{l}{ Learning objectives } \\
\hline Cognitive & $\bullet$ & Reflect on the actions taken when students do the searching process. \\
strategies & $\bullet$ & Give the feedback on exercise section (Answer the questions). \\
\hline
\end{tabular}

The second strategy for designing constructivist learning environments was based on the work by Jonassen (1999) which consist of three integrated learning components that are the problem context, the problem representation and the problem manipulation space. The instructional activities to support problem context are through modelling, the problem representation through coaching and the problem manipulation space is through scaffolding.

Modelling strategy focus on the expert's performance where it provides an example of the desired performance for an activity. The modelling in constructivist learning environments are behavioural modelling and cognitive modelling. Behavioural modelling demonstrates how to perform the activities while cognitive modelling articulates the reasoning that learners should use.

Coaching strategy focus in coaching learners to improve their performance while learning by motivating, analyse their performance, provided feedback and advice on what was learned.

Scaffolding strategy focus in guiding learners on what to consider, how to think, how to utilize the available features in the learning environment and how to analysing and approaching learning tasks or problem while learning which were classified as conceptual, metacognitive, procedural and strategic knowledge as proposed by Hannafin et al. (1999). The model of instructional design theory based on constructivist learning environments as showed in Figure 2.

E.g.

- $\quad$ Drag \& Drop Objects

- Type in reading

- Click non-sequential buttons

- Click observation options

- Type in contentions to assorted concepts

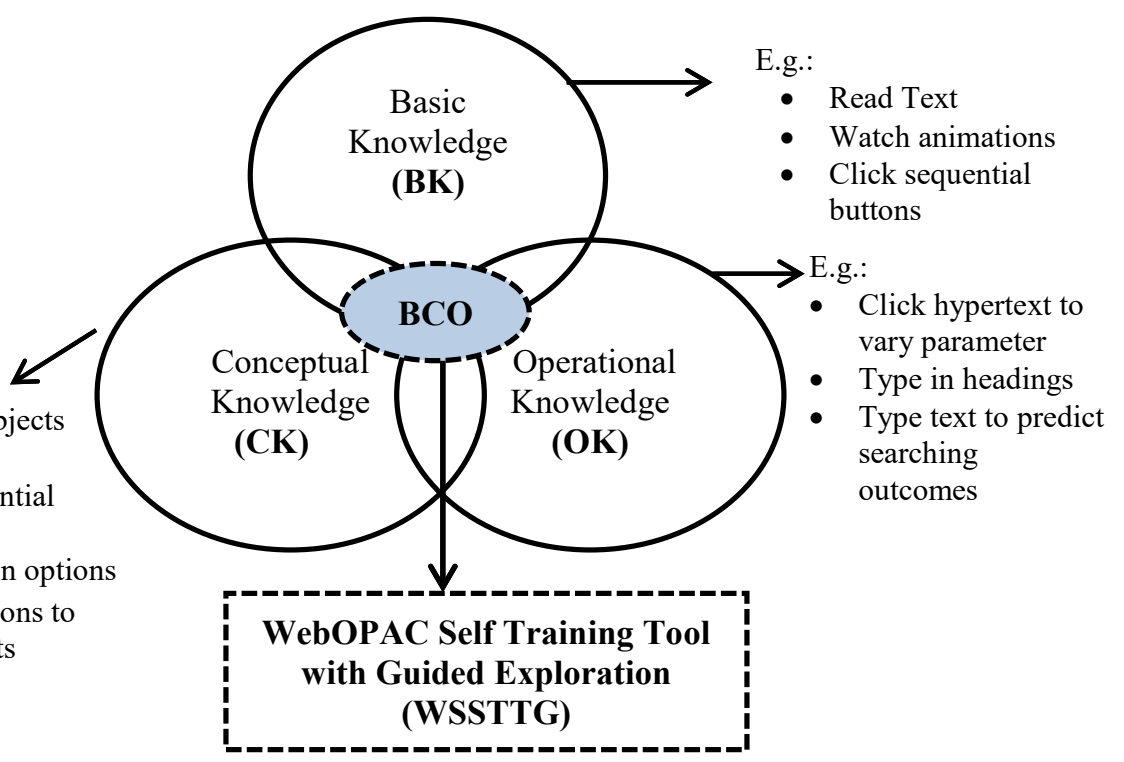

Figure 2: The Model of Instructional Design Theory based on Constructivist Learning Environment (Jonassen, 1999; Hannafin et al., 1999). 


\section{Micro Strategies}

The first micro strategy concern on the presentation strategy was based on the cognitive theory of multimedia learning proposed by Mayer (2002) which based on the knowledge construction metaphor. There are three fundamental assumptions underlying the theory which are dual channels which are a) visual or pictorial, and b) auditory or verbal processing, limited capacity and active processing. This theory assumes that human beings possess separate channels for processing visual and auditory information. Second, human beings can receive limited in the amount of information that they can process in each channel at one time. Lastly, human beings engage in active learning by coordinating set of cognitive processes during learning.

The second micro strategy concern on the seven principles for the design of instructional multimedia messages also proposed by Mayer (2002) which consists of multimedia principle, spatial contiguity principle, temporal contiguity principle, coherence principle, modality principle, redundancy principle and individual differences principle.

According to Mayer (2002), multimedia principle describes that learners learn better from words and pictures rather from words alone. Spatial contiguity principle describes that learners learn better when corresponding words and pictures are presented near rather than far from each other. Temporal contiguity principle describes that learners learn better when corresponding words and pictures are presented simultaneously rather than successively. Coherence principle describes that learners learn better when extraneous words, pictures and sounds are excluded rather than included. Modality principle describes that learners learn better from animation and narration than from animation and onscreen text. Redundancy principle describes that learners learn better from animation and narration than from animation, narration and on-screen text. Lastly, individual differences principle describes that design effects are stronger for low-knowledge learners than for high-knowledge learners and for high-spatial learners rather than for low-spatial learners.

\section{Constructivist Instructional Development Model}

Instructional development model guides the instructional design process which concerns on the process which an instructional designer should use to plan and prepare for the instruction (Reigeluth, 1999). This study applies constructivist instructional development model which differ from traditional instructional development model where the procedural models of instructional development are seen as flexible and changeable (Wilson, 1997). The reflective, recursive, design and development (R2D2) model proposed by Willis (1995) and later revised in Willis and Wright (2000) was selected because the model encourages a non-linear approach where the suggested procedures can be completed in any order that make sense. Secondly, designers may revisit any decision, product or process at any time in the design and development of the product and make refinements and revisions as needed. Lastly the model emphasises the extensive involvement of experts and users in the design and development process. 
The R2D2 model consists of two development environment components which are the tools of design and the process of design. The selection of tools of design is based on three important characteristics which are power, flexibility and accessibility. Power and flexibility are needed as it encourages experimentation and exploration of alternatives, while accessibility is needed as the model encourages participation. While the process design consists of four levels which are component design, single path prototype, alpha version and beta version.

The component design focus on developing the interface, surface characteristics, scenario, and instructional strategies. The single path prototype which has one relatively complete path through the programme has been created. Feedback from this prototype was used to create the alpha version which still have some rough versions of some materials and prepared for instructional designer evaluation purposes. After refinement and revised of the alpha version, beta version was produced. Then, the beta version was refined and revised by some selected users for feedbacks. Final prototype was introduced as completed refinement and revision were done on beta version. The process was continued until all experts and users that involved in the design and development process achieved their similar objectives and targets during evaluation.

The development process ended with four activities which were summative evaluation, final packaging, diffusion and adoption. Summative evaluation was used to assist the experts to evaluate the application usage based on the components design that have been selected. Diffusion and adoption activities were focusing on assisting facilitators and learners on how to appropriately adapt the application to the learner's local context.

\section{DISCUSSION}

Throughout the design and development process, there were two instructional designers and two subject matter experts were participated to review and evaluate the design components of the WSTTG. Both instructional designer experts were degree holders in Information Technology (IT) fields and have more than ten years experiences on design and development for online and web-based learning application systems. They also have been awarded as excellent worker in their working company. While the two subject matter experts were degree holders in library management and have more than eight years experiences in conducting library orientation training. Both were also been awarded as an excellent librarian in their universities. All experts have provided detail comments and suggestions for each version of this WSTTG testing on constructivist learning environment. All experts initially reviewed the single path prototype. Revisions were made before the subject matter experts reviewed the revised prototype.

The subject matter experts once again reviewed the alpha version of the WSTTG prototype. The instructional designer experts were not involved as they were satisfied that the instructional design and interface were consistent for all the five submenus. Review by the subject matter experts were 
necessary to ensure the accuracy and completeness of the contents presented for all contents involved. However, the subject matter experts did not see the necessity to perform any revision in that particular session. Both subject matter experts then further evaluated the alpha version in separate one-to-one evaluation sessions. The alpha version was revised after each evaluation session. Each subject matter expert was requested to explore the alpha version of the WSTTG prototype. The subject matter experts were asked to freely comments and give suggestions which regard to the content preparation.

Three potential learners were also participated to evaluate the beta version prototype whether it is appropriately to apply to their learning context. The repetition of reviewing the alpha and beta version prototypes lasted when there were no comments found during the final evaluation. Overall, all experts and learners were satisfied with the interface, surface characteristics, scenario, and instructional strategies used in the prototype after consideration on comments and suggestions have been made accordingly. The final version finally has been packaged and published where users can access via internet through the http://wsttuitm.blogspot.my/. Figure 3, 4 and 5 present the examples of interface and the contents of WSTTG application based on the constructivist instructional design theories and constructivist instructional development model.

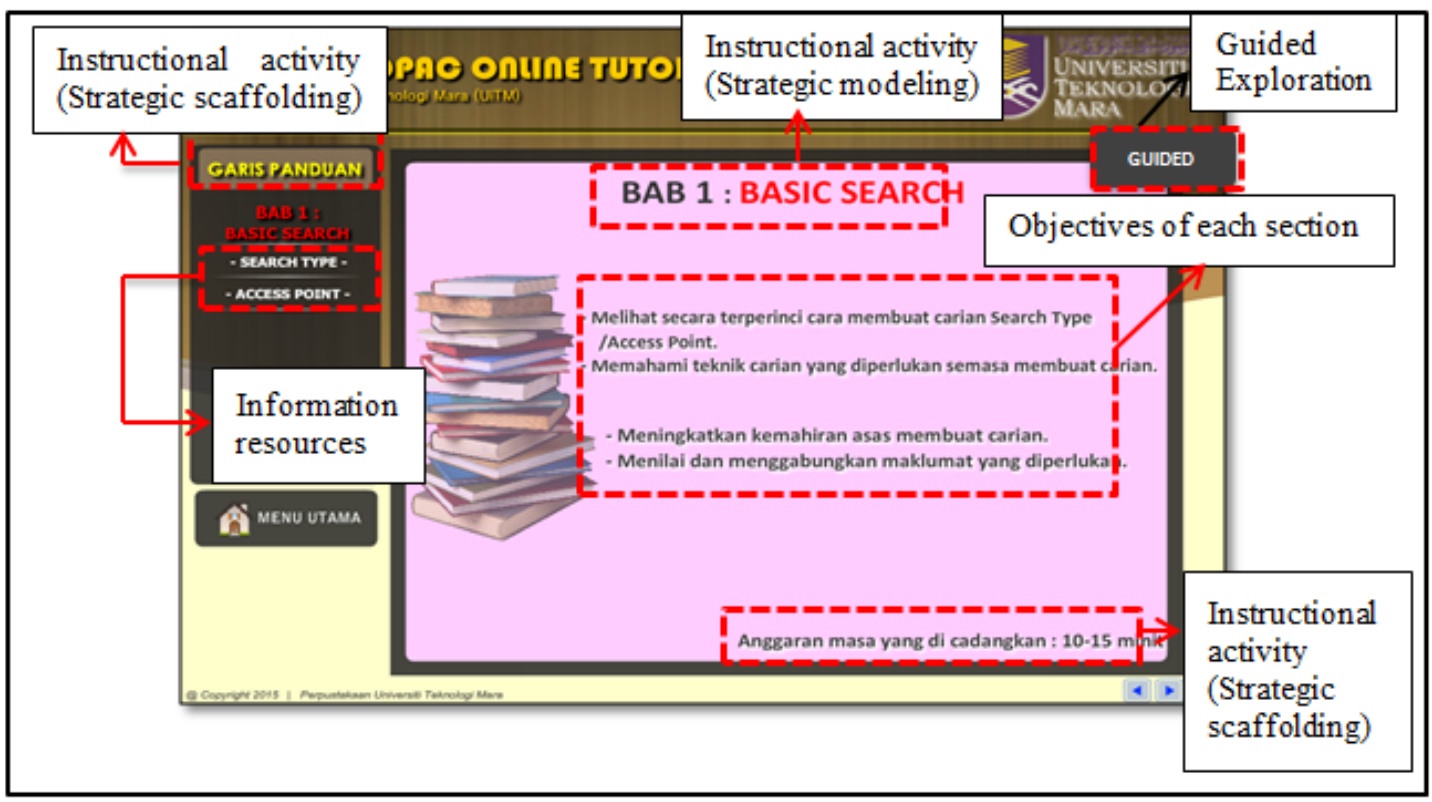

Figure 3: Example of interface and contents of WSTTG application based on Constructivist Learning Environment (Basic Search Overview) 


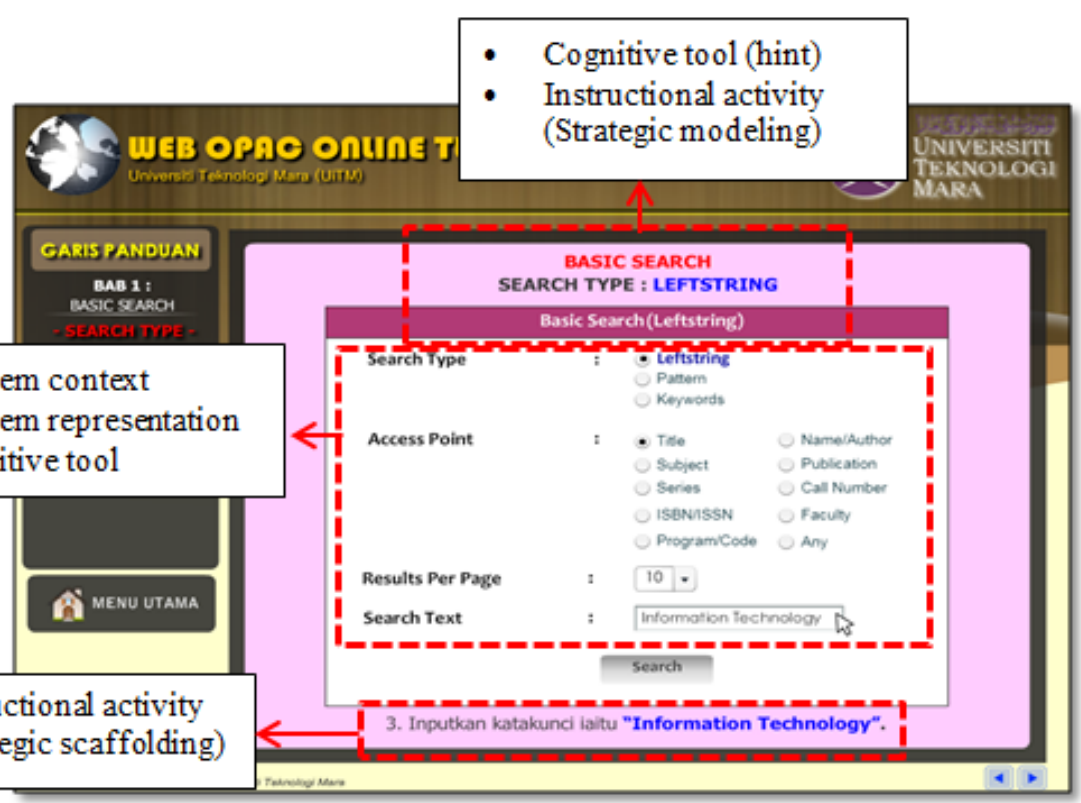

Figure 4: Example of interface and contents of WSTTG application based on Constructivist Learning Environment (Basic Search Process)

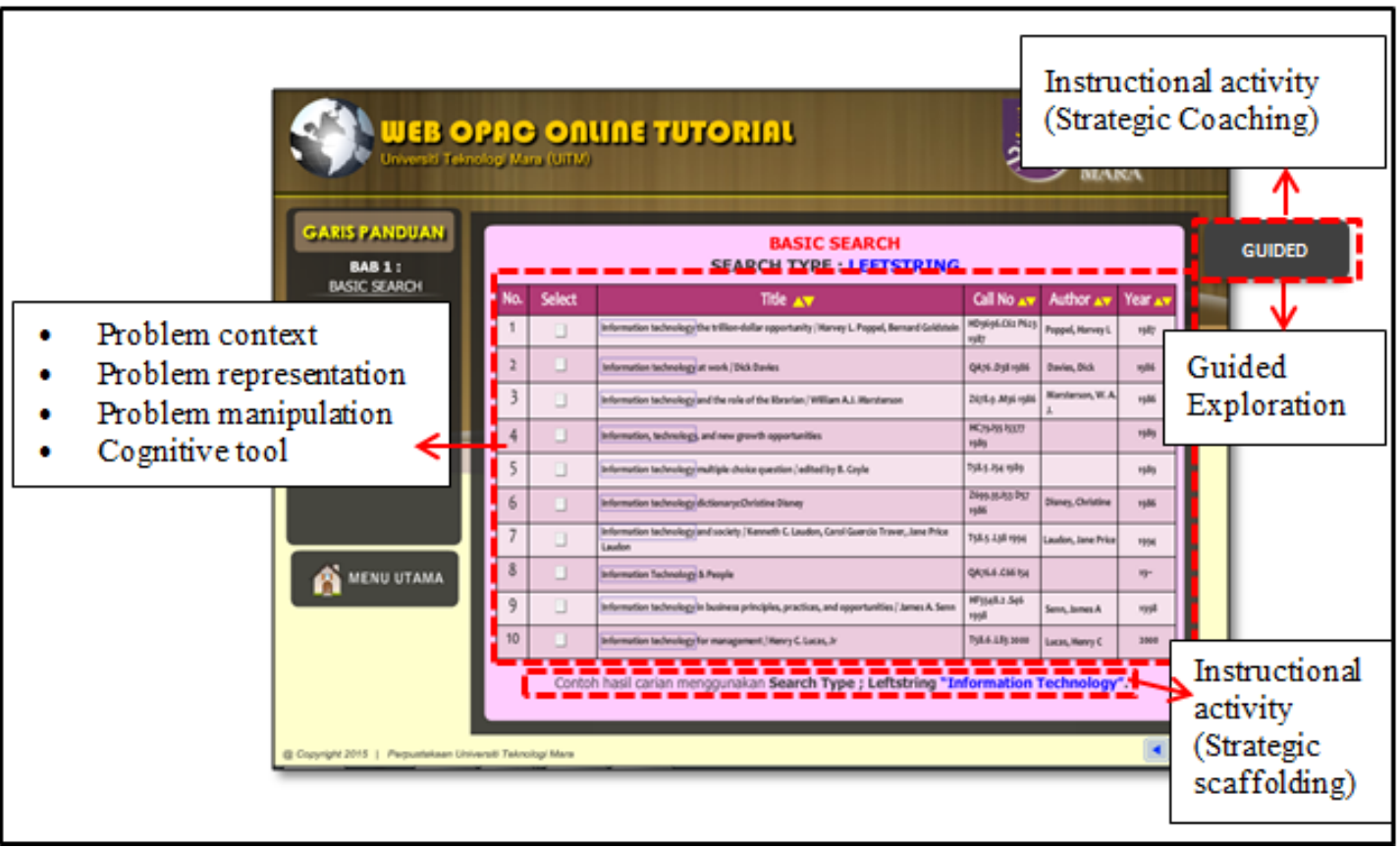

Figure 5: Example of interface and contents of WSTTG application based on Constructivist Learning Environment (Basic Search Result) 


\section{CONCLUSION}

WebOPAC Self Training Tool with Guided Exploration (WSTTG) is a unique and novel interactive multimedia web-based constructivist learning application that helps individuals to be cognitively prepared to solve their problem in searching the information using the WebOPAC services. It is an instructional strategy tool which enables individuals to recognize information need and develop their ability to locate, evaluate, and use effectively the information needed. In addition, this tool has the capability to develop and access information literacy skill among library users in using WebOPAC system. Furthermore, this tool has been developed according to the constructivist instructional design (ID) theories which comply with the ACRL Information Literacy Competency Standards for Higher Education and Bloom Taxonomy standard. This tool can be commercialized as an instructional strategy for library orientation program and to be used by both the librarians and library users for WebOPAC teaching and learning purposes. The design and development of this tool could be a guideline to future instructional designers, web developers and e-learning content specialist if they want to develop a webbased constructivist multimedia application in various fields. The future research from this study is to investigate the effects of WebOPAC Self Training Tool with Guided Exploration (WSTTG) as the learning strategy on information literacy (IL) skills standards among first year degree students in Malaysian public universities. It will also investigate the effects of the learning strategies amongst the students with high and low logical thinking level on their IL skills.

\section{ACKNOWLEDGEMENT}

This study is supported through the Academic \& Research Assimilation Scheme (ARAS) Phase 2/2016 granted from the Universiti Teknologi MARA, Malaysia (600-IRMI: 5/3/ARAS (0144/2016)).

\section{REFERENCES}

Anunobi, C., \& Udem, O. K. (2014). Information Literacy Competencies: A Conceptual Analysis. Journal of Applied Information Science and Technology, 7(2), 64-80.

Association of College and Research Libraries, ACRL. (2014). Framework for information literacy for higher education (June 2014 draft).

Association of College and Research Libraries, ACRL (2011). Standards for libraries in higher education. Chicago, Illinois: Association of College and Research Libraries, a division of the American Library Association.

Baro, E., \& Keboh, T. (2012). Teaching and fostering information literacy programmes: A survey of five university libraries in Africa. The Journal of Academic Librarianship, 38(5), 311-315. http://doi.org/10.1016/j.acalib.2012.07.001

Derakhshan, M., Hassanzadeh, M., \& Nazari, M. (2015). Developing Information Literate Librarians: A Study of LIS Academics Pedagogical Approaches in the Development of Information Literacy Competencies. Journal of Academic Librarianship, 777-785. http://doi.org/10.1016/j.acalib.2015.08.021

Edzan, N.N. (2008). Information literacy development in Malaysia: A review. Libri, 58(4), 265-280. doi:10.1515/libr.2008.027

Gagne, R.M., \& Merrill, M.D. (1990). Interative goals for instructional design. Educational Technology Research and Development, 38(1), 23-30.

Gagne, R.M., Briggs, L.J., \& Wager, W.W. (1992). Principles of instructional design (4th ed.). Forth Worth, TX: Harcourt Brace Jovanovich College Publishers. 
Gibbons, A.S., Fairweather, P.G., Anderson, T.A., \& Merrill, M.D. (1997). Simulation and computer-based instruction: A future view. In R.D. Charles \& A.J. Romiszowski (Eds.), Instructional development paradigms (pp. 269-282). New Jersey: Educational Technology Publications.

Gregory, A. S., \& Broussard, M. J. S. (2011). Unraveling the 'Mystery' of the library: A 'Big Games' Approach to Library Orientation. Proceedings of Association of College and Research Libraries (ACRL) Conference, (pp. 471-476). Philadelphia, Pennsylvania.

Gullikson, S. (2006). Faculty Perceptions of ACRL's Information Literacy Competency Standards for Higher Education. The Journal of Academic Librarianship, 32(6), 583-592. http://doi.org/10.1016/j.acalib.2006.06.001

Hannafin, M., Land, S., \& Oliver, K. (1999). Open learning environments: Foundations, methods and models. In C.M. Reigeluth (Ed.), Instructional-design theories and models - A new paradigm of instructional theory (pp. 115-140). New Jersey: Lawrence Erlbaum.

Husaini, H., Aziz, R. A., Karim, M. D. A., Jamin, J., \& Saad, D. M. S. M. (2011). Keperluan modul literasi maklumat di perpustakaan akademik di Malaysia: Kajian kes (pp. 267-287).

Jonassen, D.H. (1999). Designing constructivist learning environments. In Reigeluth, C., Instructional Design Theories and Models. (pg 217-239). Mahwah, NJ: Lawrence Erlbaum Associates.

Jyoon, M. C. L., \& Ibrahim, M. Y. (2015). Information Literacy for Sustainable Advancement: Malaysian Experience (pp. 111). http://myrepositori.pnm.gov.my/bitstream/123456789/4027/1/CONSALXVI_ChinLJ_YazidIbrahim.pdf

Kim, S. U., \& Shumaker, D. (2015). Student, Librarian, and Instructor Perceptions of Information Literacy Instruction and Skills in a First Year Experience Program: A Case Study. The Journal of Academic Librarianship, 41(4), 449-456. https://doi.org/10.1016/j.acalib.2015.04.005

Klaib, F. J. (2011). Users' ratings on the improved library orientation programme at Zarqa Private University: A comparative study. Malaysian Journal of Library \& Information Science, 16(1), 63-72.

Kumar, S. (2014). Relationship of OPAC users' satisfaction with their demographic characteristics, computer skills, user education, user assistance and user-friendly OPAC. The Electronic Library, 32(1), 106-123. https://doi.org/10.1108/EL01-2012-0002

Lanning, S., \& Mallek, J. (2017). Factors Influencing Information Literacy Competency of College Students. Journal of Academic Librarianship, 43(5), 443-450. https://doi.org/10.1016/j.acalib.2017.07.005

Magnuson, M. L. (2013). Web 2.0 and information literacy instruction: Aligning technology with ACRL standards. Journal of Academic Librarianship, 39(3), 244-251. http://doi.org/10.1016/j.acalib.2013.01.008

Mayer, R.E. (2002). Multimedia learning. Cambridge: Cambridge University Press.

Mole, V., Chatzilia, M., Paraskevopoulos, K., Garoufallou, E., \& Siantri, R. (2013). Web-based information literacy in an academic library: The example of the library of ATEI of Thessaloniki. Procedia - Social and behavioural Sciences, 73 181-187.

Nurfaezah Mamat, Mohd Nasir Ismail \& Adnan Jamaludin. (2014). Deficiencies in library orientation programs at Malaysian academic libraries. International Journal of Library and Information Studies (IJLIS), 4(3), 1-8.

Ramli, N., Fun, C. S., \& Idris, F. (2009). Kajian kepuasan pelanggan terhadap perkhidmatan perpustakaan universiti awam di Malaysia. Jurnal Pengurusan, 28, 23-43.

Reigeluth, C.M. (1999). What is instructional-design theory and how is it changing? In C.M. Reigeluth (Ed.), Instructionaldesign theories and models - A new paradigm of instructional theory (pp. 5-29). New Jersey: Lawrence Erlbaum.

Reigeluth, C.M., \& Merrill, M.D. (1978). A knowledge base for improving our methods of instruction. Educational Psychologist, 13, 54-70.

Rice, S., \& Gregor, M. N. (2013). This library orientation is fun!: Building a successful virtual tour experience for students. In $A C R L$ (pp. 583-588).

Shao, X., \& Purpur, G. (2016). Effects of Information Literacy Skills on Student Writing and Course Performance. The Journal of Academic Librarianship, 1-9. http://doi.org/10.1016/j.acalib.2016.08.006

Simon, C. R. (2013). Library and Information Literacy Instruction in Israeli Colleges and Universities: A Preliminary Survey. The International Information \& Library Review, 45(3-4), $108-113$. https://doi.org/http://dx.doi.org/10.1016/j.iilr.2013.10.004

Syamalamba, R. (2011). Information literacy programmes for undergraduate students. International Journal of Digital Library Services, 1(1), 49-61.

Thanuskodi, S. (2013). ICT literacy among library professionals in the engineering college libraries of Tamil Nadu: An analytical. International Journal of Digital Library Services, 1(2), 131-141.

Willis, J. (1995). Recursive, reflective instructional design model based on constructivist -interpretist theory. Educational Technoogy, 35(6), 5-23.

Willis, J., \& Wright, K. (2000). A general set of procedures for constructivist instructional design: The new R2D2 model. Educational Technoogy, 40(2), 5-20.

Wilson, B.G. (1997). The postmodern paradigm. In R.D. Charles \& A.J. Romiszowski (Eds.), Instructional development paradigms (pp. 297-309). New Jersey: Educational Technology Publications. 